\title{
THE POTENTIAL OF DIALECT PHONETIC MISTAKES IN TEACHING RUSSIAN AS A FOREIGN LANGUAGE
}

\author{
Suellen Martins Medina \\ Pushkin State Russian Language Institute, Russian Federation \\ Ekaterina Budnik \\ Moscow State Linguistic University, Russian Federation
}

\begin{abstract}
This article examines the problem of presenting phonetic material in texts when teaching Russian as a foreign language (RFL) to Brazilian students. Based on the methodological principles of teaching Russian phonetics, the authors discuss the importance of taking into account students' phonetic needs in selecting text in the educational process. The structure of educational materials and educational texts are analysed as an example of this approach. The authors offer to consider the national specifics of students to increase the efficiency of work on phonetics. To analyse the phonetic material present in texts and expose the specific difficulties Brazilian students experience when learning the Russian language, the authors experimented using a text from the textbook "Poekhali! 1 level". From different regions, fifty-four students were interviewed, and we presented different phonetic problems according to their dialectal characteristics. The most exciting and complex phonetic error is related to the pronunciation of the sounds $[r]-\left[r^{j}\right]$ and $[X]-\left[X^{j}\right]$; based on this type of error it is possible to determinate the provenience of the interviewed students.

Keywords: Russian as a foreign language, Russian phonetics, comparative linguistics, typological comparison, dialects of Brazilian Portuguese, linguo-ethno-oriented approach.
\end{abstract}

\section{Introduction}

A linguo-ethno-oriented approach to teaching Russian as a foreign language is based on the indispensable consideration of the peculiarities of the studied language through the prism of the native language (or the intermediary language) and conscious reliance on him in the course of a specially organized and controlled educational process for different ethnic groups.

The communicative orientation of modern teaching RFL, determining the interconnected and parallel formation of the language, speech and communicative competences of students, determines the corresponding presentation the development of language material in textbooks addressed to native speakers of specific languages. 
The text is introduced into the educational process not separately, but in close connection with the presentation of phonetic material (Cunha \& Cintra, 2008). Since the text gives students examples of the living use of those language units to be mastered, its use in the educational process provides students with an understanding of phonetic units not as separate sounds, but as an inseparable side of the language. Providing a phonetic minimum for each stage of development, the teacher must select texts as efficiently as possible in accordance with the needs of his audience.

In the conditions of teaching RFL to a certain nationality, it is necessary to consider their characteristics, including phonetic aspects. The phonetic minimum is not determined by native language of a student, but the difficulties in achieving it at each stage of education depend on national specifics.

The characteristics of students' native language should determine the differences like educational comments, the measure of attention to a particular linguistic fact, the choice of methods for staging Russian sounds and methods of semantization lexical units, the sequence of studying linguistic phenomena and the nature of their presentation. Furthermore, with the help of special methodological techniques, a teacher can limit the phenomenon of interference. However, the stimulation and inhibition of the transference should be carried out mainly through specially selected exercises and partially instructions, but not by a comparative analysis of the two languages

\section{Literature Review}

The accessibility of the text is closely related to the national specifics of the student, because it is on the structures and concepts offered by his native language that his perception of the linguistic specifics in a foreign language depends. Therefore, it becomes necessary to consider methodological principles when selecting a suitable text; the principle of gradualness is especially important. Since the student's difficulties are determined in accordance to the peculiarities of his/her native language, especially in teaching phonetics, the mastering of phonetic material through texts will be realized precisely according to the similarities and differences of the native language in comparison with the foreign language. To teach RFL to Brazilian students, therefore, they have to consider their national phonetic difficulties when studying a foreign language, which has initially been described by Budnik (2007) and posteriorly explored by Medina (2020):

a) violation of the softness feature can lead to a phonetic error based on substitution and, consequently, to the phonological replacement of soft consonants with hard ones due to the underdifferentiation of these phonemes; 
b) vowel rate in an attempt to reproduce soft consonants due to the fact that softness in Russian $\mathrm{AB}$ leads to the development of places of formation that differ from Brazilian AB (middle palate $\left[\kappa^{\prime}\right]-\left[\Gamma^{\prime}\right]$ and $\left[\mathrm{x}^{\prime}\right]$ ) and ways of formation (soft [t '] - [d']).

These indications of phonetic discrepancies must be count on the selection of Russian text for the Brazilian audience.

To identify the regional specifics of the speech of the speaker in Russian N. S. Smirnova and M. V. Khitrov developed a phonetically representative text, which content reflects the general linguistic distribution of phonetic units (phonemes, allophones and syllables); their frequency was statistically determined by the authors (Smirnova \& Khitrov, 2013). The texts developed by N. S. Smirnova and M. V. Khitrov, on the one hand, are an excellent test material for students of the advanced stage, but on the other hand, they cannot be used in our work, since they do not imply the stages of mastering RFL, but reflect the entire phonetic complexity of the Russian language.

At the initial stage of learning, the limited number of words, according to Shchukin (2017), is 750 words at A1 and 1500 words at A2, which does not allow flexible supply of new words. However, the process of expanding vocabulary at the initial stage should be carried out respecting the possibilities of its mastery by students, which presents many options in terms of phonetics. Therefore, it is highly recommended not to overload the texts with words and phrases, the phonetic properties of which coincide with the above-mentioned difficulties, but the text should fulfill the function of making the student's development considering its complexity. It is in the articulation of these two principles that the balance of the text is determined: not too complex while not too light.

\section{Methodology}

Since the methodology of teaching RFL is not sufficiently developed in Brazil, a teaching material of textbook does not reflect the peculiarities of native language. The analyzed text is Пешком ходить - долго жить "Walking on foot - to live a long time" was introduced into the textbook Poekhali! 1 level in lesson 20, page 165, when work on phonetics is no longer in the very structure of the material (Chernyshov, 2009).

Fifty-four Brazilian students from different regions had their reading of the following text recorded. The resulting material was then compared to the expected patterns of pronunciation errors.

Пешком ходить - долго жить

Было время, когда люди только ходили пешком, потом - долго ездили на лошадях. Ломади очень красивые и не едят дорогой бензин. Ломадь - очень 
экологичный транспорт. На лощади вы можете ехать, куда хотите, даже в лес. И в наше время люди на далёком севере ездят на собаках, и в северных странах, например, в Канаде, это новый популярный спорт. Собаки - хорошие друзья и дешёвый транспорт, только не очень быстрый. Во многих странах модно ездить на велосипеде. Это хорошо в городах, где есть специиальные велосипедные дороги. В Америке индейцы, в принципе, знали колесо, играли в «футбол», но никогда не ездили. В последнее время люди, особенно в богатых странах, больше и больше ездят на машинах: на работу, на отдых, в гости и даже в соседний магазин. Во многих странах хорошая машина - это престиж. Сколько же ходит пешком современный человек? Вот что говорят об этом английские специалисты: средний европееи за свою жизни ходит пешком 80500 километров. Кажется, немало. Но, если он живёт 70 лет, то ходит 3 километра в день. А в России говорят: «Пешком ходить - долго жить!»

Walking on foot - living long

There was a time when people only walked, then they rode horses for a long time. The horses are very pretty and do not eat expensive gasoline. The horse is a very environmentally friendly transport. On a horse, you can go wherever you want, even into the forest. And nowadays people in the far north ride dogs, and in northern countries, for example, in Canada, this is a new popular sport. Dogs are good friends and cheap transport, but not very fast. Cycling is fashionable in many countries. This is good in cities where there are special bike paths. In America, the Indians, in principle, knew the wheel, played football, but never drove. Recently, people, especially in rich countries, drive more and more: to work, to rest, to visit, and even to a nearby store. In many countries, a good car is prestige. How long does a modern man walk? Here's what British experts say about it: the average European walks 80,500 kilometers in his lifetime. It seems a lot. But if he lives for 70 years, then he walks 3 kilometers a day. And in Russia they say: "To walk on foot to live a long time!"

In this text, there are examples of sounds which pronunciation allows to check the difficulty of reproducing such soft sounds as consonants without a vowel after them. The first group of errors is divided into two subgroups: when there is a soft vowel after a soft consonant: лю $\underline{\partial} u$, ез $\underline{\partial} u л u$; the second one is composed by soft consonants with soft sign: только, очень , лошады, ходить

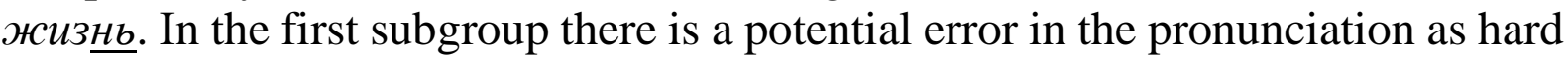
sound: лю[dz]u, ез[dz]или, while in the second one it is expected the

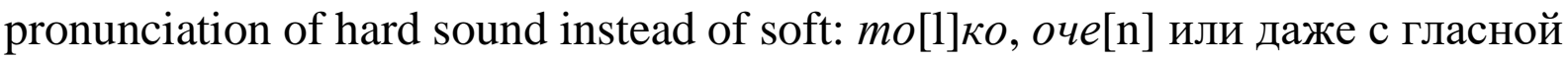
ставкой: лоша[dzi], ходи[t $\mathrm{ji}$, жиз[ni]. The last three errors are included in the second group, marked by the vowel addition: когд $а-\kappa о$ [gi] $\partial а$, едя $\underline{m}-е \partial я\left[\mathrm{t} \int \mathrm{i}\right]$,

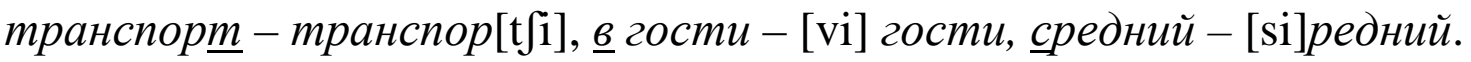

It is noted that the error of the vowel addition can lead to a grammatical one in cases of pronouncing nouns with a soft sign or a consonant at the end, as can be noted in the nouns транспор $\underline{m}$ and лошад $\underline{\partial b}$, which pronunciation with [i] in the end changes the number of the noun to the plural. 
It is also important to note that when pronouncing words with a soft sign at the end, the student must overcome difficulties related to both groups of errors. These soft sounds are therefore particularly difficult for Brazilian students.

Another important dialectal mark of the students' discourse is the pronunciation of $[\mathrm{x}]-\left[\mathrm{x}^{\mathrm{j}}\right]$ and $[\mathrm{r}]-\left[\mathrm{r}^{\mathrm{j}}\right]$ after vowel. In Portuguese language there is an alternance of $[\mathrm{x}]$ and $[\mathrm{r}]$ corresponding to the same letter pronunciation, that is the word mar 'sea' may be spoken as ma[x], ma[r] or even $[\mathrm{x}]$ depending on the students' provenience, as described by Silva (2003, p. 51). Such pattern leads to the potential misinterpretation of the sounds [x] and [r] after vowel in Russian, which may result in the following errors: лошадяx 'horses' - лошадя[r] or лошадя[..] and собаках 'dogs' - собака[r] or собака[I], as well as популярный 'popular' - популя[х]ный оr популя[I] ный and транспорт 'transport' транспо [х]m оr транспо[I]m.

\section{Research Results}

The experiment was conducted with qualitative analysis of data. We compared the phonological systems of Brazilian and Russian languages. The students read the texts in Russian, we described their mistakes considering the phonetical interference. The students from nine Brazilian states. The majority of them presented problems with the soft pronunciation, as expected. The vowel addition was observed in the students in the initial level, but less frequently in the ones in the intermediate.

The variety of levels of the analyzed students allows to identify which errors persist after some progress in learning. As said before, the majority of the students presented the same error when pronouncing soft sounds: xодumb - xo['dzi.tfr], ездили - ез[dzi]ли, хотите - хо ['t $\mathrm{fi} . \mathrm{t} \int \mathrm{e}$ ], жить - жи[t] $\mathrm{I}$ ], лошади - лоша[dzI], можете - може $[\mathrm{t} \mathrm{f} \mathrm{I}]$. The vowel addition is also observed independent of the student's provenience: специалисты - [is]пециалисты, страна - [is]страна, спорт - [is]nорт, только - то[1]ко, транспорт - транспор[t $\mathrm{f} \mathrm{I}]$.

We identified very interesting possibilities regarding the pronounciation of the sound $[\mathrm{r}]$ after vowel. As predicted, the alternance occured according to the pronunciation in the student's dialect: the mispellings cnopm - cno $[\mathrm{x}] m$, транспорт - транспо[х]m, например - наприме[x] were commited by the ones from the states Ceará and Rio de Janeiro, while северных - севе[I] ныхx, сnорm спо[I] $m$, транспорт - транспо[.. $]$ m, например - наприме[I] were pronounced by the ones from the country sides of different south and southeast states. It is also relevant to consider the supression of this sound in the end of the word: собакаx собака[-], странах - страна[-] happened with one student from the state Ceará, which does not permit yet to consider it a pattern, but it opens possibilities for 
further investigation. Such supression may happen in different places in Brazil (Cardoso, 2009).

\section{Conclusions}

Thus, a linguo-ethno-oriented approach to the production of Russian sounds necessarily requires an RFL teacher to know which moments of articulation are new for students of a certain nationality (in our case - Brazilian), and which are only similar to the sounds of his native language; violation of which moments of articulation lead to mixing of sounds (phonological error), and which ones lead to a slight accent (phonetic error).

To optimize the teaching of Russian pronunciation, the volume and sequence presentation of phonetic material should be determined by comparing the phonological systems of the native and studied languages and considering phonological features of the native language of students.

When setting sounds, a student should rely not only on imitation but also on controlled and tangible articulation in Russian. Since the pronunciation skills formed by imitation are unstable, it leads to a mixing of similar sounds in contacting languages.

\section{References}

Budnik, E. A. (2007). Osobennosti inostrannogo akcenta na baze russko-portugal'skogo dvujazychija studentov Afriki i Latinskoj Ameriki. IX nauchno-prakticheskaja konferencija molodyh uchenyh. Aktual'nye problemy russkogo jazyka i metodiki ego prepodavanija: RUDN, 27 aprelja 2007 goda. Moscow: Flinta: Nauka.

Cardoso, D. P. (2009). Fonologia da língua portuguesa. São Cristóvão: Universidade Federal de Sergipe, CESAD.

Chernyshov, S.E. (2009). Let's go! Russian for adults. A course for beginners. 7th ed. St. Petersburg: Zlatoust.

Cunha, C., \& Cintra, L. (2008). Nova gramática do português contemporâneo. 5a ed. Rio de Janeiro: Lexikon.

Medina J. P., Medina S. M., \& Budnik, E. A. (2020). Linguistic errors of Brazilian students when learning Russian as a foreign language (basic level). Society. Integration. Education. International Scientific Conference, 2020, Rezekne Academy of Technologies. Volume V, 505-520. DOI: https://doi.org/10.17770/sie2020vol5.5097

Silva, T. C. (2003). Fonética e fonologia do Português: roteiro de estudes e guia de exercícios. Taís Cristófaro Silva. 7 ed. São Paulo: Contexto.

Shchukin, A. N. (2017). Metodika prepodavanija russkogo jazyka kak inostrannogo. Moscow: FLINTA.

Smirnova, N. S., \& Khitrov, M. V. (2013). Foneticheski predstavitel'nyj tekst dlja fundamental'nyh i prikladnyh issledovanij russkoj rechi. Izvestija vysshih uchebnyh zavedenij. Priborostroenie, 56 (2), 5-10. 